\title{
Analisa Peralihan Tanggapan Tegangan Sistem Automatic Voltage Regulator (AVR) Tipe Arus Searah Dengan Pengendali 2 Derjat Kebebasan
}

\author{
Heru Dibyo Laksono ${ }^{1}$, Novizon ${ }^{1}$, Janra Isram ${ }^{1}$ \\ ${ }^{1}$ Jurusan Teknik Elektro, Fakultas Teknik Universitas Andalas \\ herudibyolaksono@eng.unand.ac.id
}

\begin{abstract}
ABSTRAK
Jurnal ini membahas perancangan dan analisa tanggapan peralihan tegangan sistem Automatic Voltage Regulator (AVR) tipe arus searah dengan pengendali 2 derjat kebebasan. Sistem AVR tipe arus searah direpresentasikan dalam bentuk fungsi alih. Untuk pengendali 2 derjat kebebasan dirancang dengan menggunakan arsitektur paralel dengan bantuan perangkat lunak Matlab dengan menggunakan kriteria perancangan yang sudah ditetapkan. Adapun jenis - jenis pengendali yang digunakan terdiri Proporsional Diferensial (PD), Proporsional Integral (PI), Proporsional Integral Diferensial (PID), Proporsional Diferensial Dengan Filter Orde Satu Pada Bagian Diferensial (PDF) dan Proporsional Intregral Diferensial Dengan Filter Orde Satu Pada Bagian Diferensial (PIDF). Untuk analisa peralihan, parameter yang diamati terdiri waktu naik, waktu puncak, waktu keadaan mantap, nilai lewatan maksimum dan nilai puncak. Hasil analisa memperlihatkan bahwa pengendali yang memenuhi kriteria perancangan adalah pengendali Proporsional Diferensial (PD) dengan nilai parameter waktu naik sebesar 0.2808 detik, waktu puncak sebesar 1.3354 detik, waktu keadaan mantap sebesar 0.7017 detik, lewatan maksimum sebesar $0 \%$ dan nilai puncak sebesar 0.9512. Untuk pengendali Proporsional Diferensial Dengan Filter Orde Satu Pada Bagian Diferensial (PDF) dengan nilai parameter waktu naik sebesar 0.4177 detik, waktu puncak sebesar 1.4684 detik, waktu keadaan mantap sebesar 0.8453 detik, lewatan maksimum sebesar $0 \%$ dan nilai puncak sebesar 0.9502 .
\end{abstract}

kata kunci : AVR, analisa peralihan, 2 derjat kebebasan

\section{PENDAHULUAN}

Kebutuhan akan energi listrik sangat penting sekali dalam kehidupan. Mulai dari industri besar, industri menengah, industri kecil sampai rumah tangga memerlukan listrik untuk mendukung kehidupan seharihari. Untuk memenuhi kebutuhan energi listrik yang sangat besar ini maka diperlukan banyak pembangkit listrik yang nantinya harus memberikan pelayanan secara kontinu. Pusat - pusat pembangkit listrik yang ada harus dapat selalu memenuhi kebutuhan beban yang berubah ubah serta daya yang tersedia dalam sistem tenaga listrik haruslah cukup untuk memenuhi kebutuhan tenaga listrik dan pelanggan.

Permasalah yang terjadi dalam pengoperasi sistem tenaga listrik adalah daya yang dibangkitkan tidak sama dengan daya yang dikonsumsi oleh pemakai tenaga listrik karena daya yang tersedia tergantung kepada daya yang terpasang pada unit - unit pembangkit dalam sistem dan juga tergantung dari kesiapan operasi unit tersebut.

Dalam pembangkitan tenaga listrik untuk di salurkan dan didistribusikan ke para konsumen, dibutuhkan sebuah generator sebagai peralatan utamanya. Hal yang sangat penting dalam proses pembangkitan tenaga listrik yaitu pada kestabilan kinerja generator dalam menyuplai daya ke sistem (beban). Proses pembangkitan tenaga listrik tersebut dipengaruhi oleh perubahan kebutuhan daya reaktif pada beban. Adanya perubahan daya reaktif yang terjadi sangat mempengaruhi kestabilan dari tegangan keluaran terminal yang dihasilkan oleh generator. Tegangan keluaran tersebut harus diubahubah agar generator tetap dalam keadaan stabil dalam mengkompensasi kebutuhan daya reaktif dari beban. Untuk Mengantisipasi hal tersebut digunakan sebuah peralatan yang dapat mengatur tegangan keluaran dari generator, yaitu dengan cara mengatur arus eksitasi pada generator secara otomatis, menggunakan sistem eksitasi generator. Pengaturan arus eksitasi secara otomatis tersebut dilakukan menggunakan sistem AVR. Sistem AVR adalah suatu sistem yang digunakan untuk menjaga kestabilan tegangan keluaran dari generator yang bergantung pada eksitasi.

Ada beberapa tipe sistem AVR diantaranya sistem AVR tipe Arus Searah, sistem AVR tipe Arus Searah dengan rate output feedback, sistem AVR tipe Arus Searah dengan transient gain reduction dan sistem AVR tipe Arus statik [1]. Tipe - tipe sistem AVR ini mempuyai performansi peralihan yang berbeda - beda. Untuk analisa peralihan dimana waktu naik, waktu puncak dan waktu keadaan mantap, model sistem AVR tipe statik memiliki nilai yang paling kecil dan untuk lewatan maksimum dan nilai puncak, model sistem AVR tipe arus searah dengan Transient Gain Reduction 
memiliki nilai yang paling kecil [1]. Hasil analisa juga memperlihatkan bahwa sistem AVR tipe arus searah memiliki performansi peralihan yang kurang memuaskan. Untuk itu dalam penelitian akan difokuskan pada perancangan dan analisa performansi peralihan sistem AVR tipe arus searah.

Adapun beberapa penelitian yang sudah dilakukan berkaitan dengan penelitian ini diantaranya [2], membahas tentang analisa peralihan, analisa performansi dalam domain frekuensi dan analisa kekokohan dari sistem AVR tipe arus searah. Pengendali yang digunakan yaitu Proporsional Integral Diferensial (PID), Proporsional Integral Diferensial plus pengendali Diferensial orde 2 (PIDD2), Proporsional Integral Diferensial (PID) dengan algoritma Particle Swarm Optimization (PSO) dan First Order Proporsional Integral Diferensial (FOPID). Hasil dari penelitian dimana performansi peralihan sistem AVR tipe arus searah dengan pengendali Proporsional Integral Diferensial plus pengendali Diferensial orde 2 (PIDD2) mempuyai performansi peralihan yang lebih baik. [3], membahas tentang perancangan pengendali Proporsional Integral Diferensial (PID) dengan algoritma Particle Swarm Optimization (PSO). Analisa yang dilakukan meliputi analisa peralihan. Berdasarkan penjelasan diatas maka dalam penelitian ini dilakukan perancangan dan analisa performansi peralihan sistem AVR tipe arus searah dengan pengendali 2 derjat kebebasan.

Tujuan dari penelitian ini untuk memperoleh informasi analisa peralihan dari tanggapan tegangan sistem AVR tipe arus searah tanpa dan dengan pengendali 2 derjat kebebasan serta jenis pengendali yang memenuhi kriteria perancangan. Untuk batasan masalah dalam penelitian ini adalah

1. Hubungan pembebanan pada saluran tidak dibahas pada penelitian.

2. Model sistem AVR yang dibahas adalah model sistem AVR tipe arus searah.

3. Sistem AVR direpresentasikan dalam bentuk fungsi alih.

4. Perancangan dan analisa dilakukan dalam tahap simulasi dengan bantuan perangkat lunak Matlab.

\section{TINJAUAN PUSTAKA}

Bagian ini mendeskripsikan pemodelan sistem Automatic Voltage Regulator (AVR) tipe arus searah, pengendali dengan 2 derjat kebebasan dan analisa peralihan. Pemodelan matematis sistem AVR tipe arus searah meliputi pemodelan amplifier, pemodelan eksiter dan pemodelan generator. Untuk pemodelan matematis amplifier dinyatakan dalam bentuk persamaan (1) berikut [4]

$$
\mathrm{G}_{\mathrm{a}}(\mathrm{s})=\frac{\mathrm{K}_{\mathrm{A}}}{1+\tau_{\mathrm{A}} \mathrm{s}}
$$

Hasil pemodelan matematis amplifier berupa fungsi alih orde satu dengan 2 parameter yaitu konstanta penguatan amplifier dan konstanta waktu amplifier. Nilai konstanta penguatan amplifier memiliki rentang nilai dari 10 sampai 400 sedangkan nilai konstanta waktu amplifier memiliki rentang nilai dari 0.02 detik sampai 0.10 detik [5]. Untuk pemodelan matematis eksiter dinyatakan dalam bentuk persamaan (2) berikut [4]

$$
\mathrm{G}_{\mathrm{e}}(\mathrm{s})=\frac{\mathrm{K}_{\mathrm{E}}}{1+\tau_{\mathrm{E}} \mathrm{s}}
$$

Hasil pemodelan matematis eksiter ini berupa fungsi alih orde satu dengan 2 parameter yaitu konstanta penguatan eksiter dan konstanta waktu eksiter. Nilai konstanta penguatan eksiter ini memiliki rentang nilai dari 10 sampai 400 dan nilai konstanta waktu eksiter memiliki rentang nilai dari 0.50 sampai 1 [5]. Untuk pemodelan matematis generator dinyatakan dalam bentuk persamaan (3) berikut [4]

$$
\mathrm{G}_{\mathrm{G}}(\mathrm{s})=\frac{\mathrm{K}_{\mathrm{G}}}{1+\tau_{\mathrm{G}} \mathrm{s}}
$$

Hasil pemodelan matematis generator ini berupa fungsi alih orde satu dengan 2 parameter yaitu konstanta penguatan generator dan konstanta waktu generator. Nilai konstanta penguatan generator memiliki rentang nilai dari 0.70 sampai 1 sedangkan nilai konstanta waktu generator memiliki nilai rentang nilai dari 1 detik sampai 2 detik pada keadaan beban nol sampai keadaan beban penuh [5]. Selanjutnya komponen - komponen sistem AVR tipe arus searah ini digabungkan dan terbentuk diagram blok dari sistem AVR tipe arus searah yang diperlihatkan pada Gambar 1 berikut

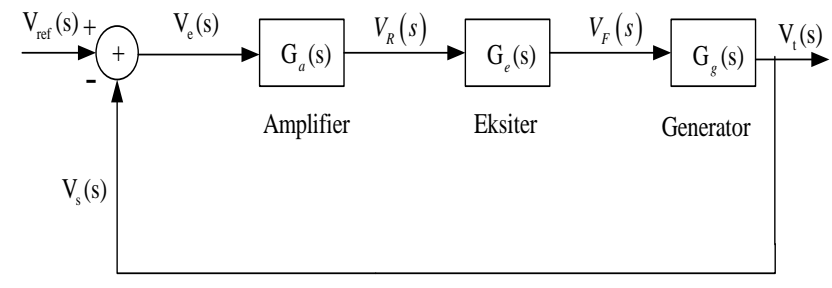

Gambar 1. Diagram Blok Sistem AVR Tipe Arus Searah [4]

Berdasarkan diagram blok pada Gambar 1. kemudian diperoleh fungsi alih lingkar terbuka dan fungsi alih lingkar tertutup dari sistem AVR tipe arus searah. Untuk fungsi alih lingkar terbuka diperlihatkan pada persamaan (4) dan fungsi alih lingkar tertutup diperlihatkan pada persamaan (5) berikut

$$
\mathrm{G}(\mathrm{s}) \mathrm{H}(\mathrm{s})=\mathrm{G}_{\mathrm{a}}(\mathrm{s}) \mathrm{G}_{\mathrm{e}}(\mathrm{s}) \mathrm{G}_{\mathrm{G}}(\mathrm{s})
$$




$$
\frac{\mathrm{V}_{\mathrm{t}}(\mathrm{s})}{\mathrm{V}_{\mathrm{ref}}(\mathrm{s})}=\frac{\mathrm{G}_{\mathrm{a}}(\mathrm{s}) \mathrm{G}_{\mathrm{e}}(\mathrm{s}) \mathrm{G}_{\mathrm{G}}(\mathrm{s})}{1+\mathrm{G}_{\mathrm{a}}(\mathrm{s}) \mathrm{G}_{\mathrm{e}}(\mathrm{s}) \mathrm{G}_{\mathrm{G}}(\mathrm{s})}
$$

Untuk diagram blok sistem AVR tipe arus searah dengan pengendali diperlihatkan pada Gambar 2 berikut

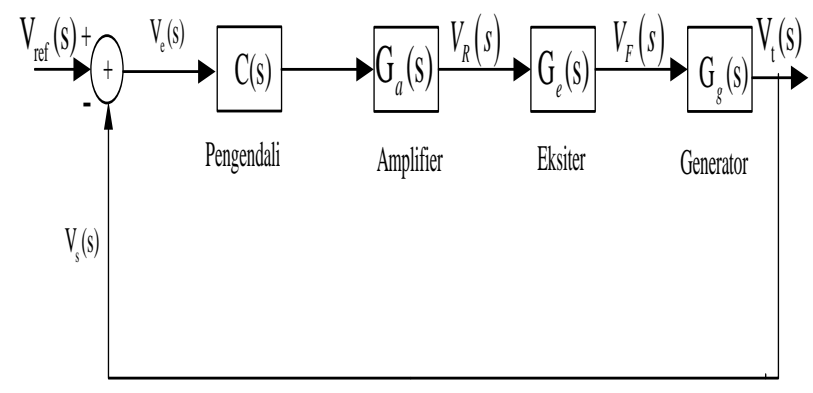

Gambar 2. Diagram Blok Sistem AVR Tipe Arus Searah Dengan Pengendali [4]

Berdasarkan diagram blok pada Gambar 2 kemudian diperoleh fungsi alih lingkar terbuka dan fungsi alih lingkar tertutup dari sistem AVR tipe arus searah dengan pengendali. Untuk fungsi alih lingkar terbuka diperlihatkan pada persamaan (6) dan fungsi alih lingkar tertutup diperlihatkan pada persamaan (7) berikut

$$
\begin{aligned}
& \mathrm{G}(\mathrm{s}) \mathrm{H}(\mathrm{s})=\mathrm{C}(\mathrm{s}) \mathrm{G}_{\mathrm{a}}(\mathrm{s}) \mathrm{G}_{\mathrm{e}}(\mathrm{s}) \mathrm{G}_{\mathrm{G}}(\mathrm{s}) \\
& \frac{\mathrm{V}_{\mathrm{t}}(\mathrm{s})}{\mathrm{V}_{\mathrm{ref}}(\mathrm{s})}=\frac{\mathrm{C}(\mathrm{s}) \mathrm{G}_{\mathrm{a}}(\mathrm{s}) \mathrm{G}_{\mathrm{e}}(\mathrm{s}) \mathrm{G}_{\mathrm{G}}(\mathrm{s})}{1+\mathrm{C}(\mathrm{s}) \mathrm{G}_{\mathrm{a}}(\mathrm{s}) \mathrm{G}_{\mathrm{e}}(\mathrm{s}) \mathrm{G}_{\mathrm{G}}(\mathrm{s})}
\end{aligned}
$$

Untuk pengendali 2 derjat kebebasan menggunakan arsitektur paralel. Adapun diagram blok pengendali 2 derjat kebebasan model paralel ini diperlihatkan pada Gambar 3. berikut

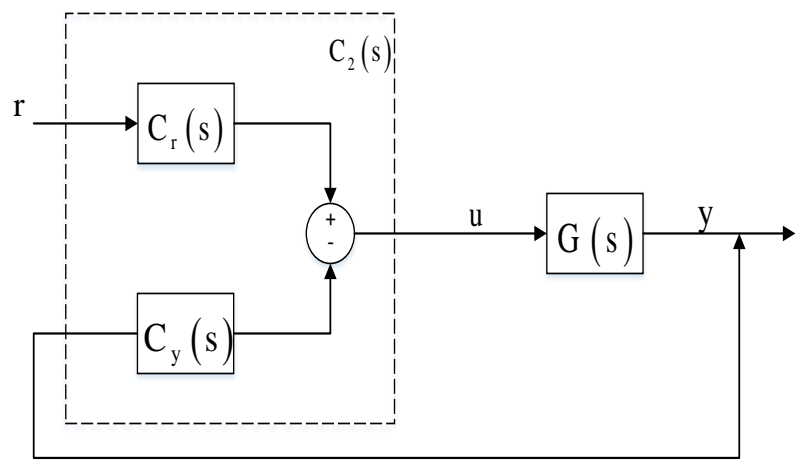

Gambar 3. Diagram Blok Pengendali 2 Derjat Kebebasan [6] Adapun persamaan pengendali yang digunakan diperlihatkan

$$
\begin{aligned}
& \text { pada persamaan (8) s/d (10) berikut } \\
& \mathrm{C}_{\mathrm{r}}(\mathrm{s})=\mathrm{bK}_{\mathrm{p}}+\frac{\mathrm{K}_{\mathrm{i}}}{\mathrm{s}}+\frac{\mathrm{cK}_{\mathrm{d}} \mathrm{s}}{\mathrm{T}_{\mathrm{f}} \mathrm{s}+1}
\end{aligned}
$$

$$
\begin{aligned}
& C_{y}(s)=-\left[K_{p}+\frac{K_{i}}{s}+\frac{K_{d} s}{T_{f} s+1}\right] \\
& u=K_{p}(b r-y)+\frac{K_{i}}{s}(r-y)+\frac{K_{d} s}{T_{f} s+1}(c r-y)
\end{aligned}
$$

Untuk jenis pengendali yang digunakan terdiri dari pengendali Proporsional Diferensial (PD), Proporsional Integral (PI), Proporsional Integral Diferensial (PID), Proporsional Diferensial Dengan Filter Orde Satu Pada Bagian Diferensial (PDF) dan Proporsional Intregral Diferensial Dengan Filter Orde Satu Pada Bagian Diferensial (PIDF). Untuk parameter yang dihitung dalam analisa peralihan ini terdiri waktu naik, waktu puncak, waktu keadaan mantap, nilai puncak dan lewatan maksimum. Untuk penentuan parameter parameter tanggapan peralihan ini bisa diperoleh dari referensi [7-8].

\section{METODA PENELITIAN}

Bagian ini menjelaskan data - data parameter sistem AVR tipe arus searah, kriteria perancangan dan prosedur analisa peralihan tanggapan peralihan tegangan sistem AVR dengan pengendali 2 derjat kebebasan.

\section{A. Data-Data Parameter Sistem AVR Tipe Arus Searah}

Parameter-parameter sistem AVR tipe arus searah yang digunakan dalam penelitian ini diperlihatkan pada Tabel 1. berikut [2]

Tabel 1. Nilai Parameter AVR Tipe Arus Searah

\begin{tabular}{cc}
\hline Parameter & Nilai \\
\hline $\mathrm{K}_{\mathrm{a}}$ & 20.0000 \\
$\mathrm{~T}_{\mathrm{a}}$ & 0.0600 \\
$\mathrm{~K}_{\mathrm{e}}$ & 1.0000 \\
$\mathrm{~T}_{\mathrm{e}}$ & 0.2000 \\
$\mathrm{~K}_{\mathrm{g}}$ & 0.8000 \\
$\mathrm{~T}_{\mathrm{g}}$ & 1.5000 \\
\hline
\end{tabular}

Data - data pada Tabel 1 kemudian disubstitusikan ke persamaan (4) s/d (5) serta diperoleh fungsi alih lingkar terbuka dan lingkar tertutup sistem AVR tipe arus searah tanpa pengendali yang dinyatakan dalam bentuk persamaan (11) dan (12) berikut

$\mathrm{G}(\mathrm{s}) \mathrm{H}(\mathrm{s})=\frac{10.00}{0.0004 \mathrm{~s}^{4}+0.0454 \mathrm{~s}^{3}+0.5550 \mathrm{~s}^{2}+1.51 \mathrm{~s}+1.00}$

$\frac{\mathrm{V}_{\mathrm{t}}(\mathrm{s})}{\mathrm{V}_{\text {ref }}(\mathrm{s})}=\frac{10.00(1+0.01 \mathrm{~s})}{(1+0.10 \mathrm{~s})(1+0.40 \mathrm{~s})(1+1.00 \mathrm{~s})(1+0.01 \mathrm{~s})+10.00}$ 


\section{B. Kriteria Perancangan}

Adapun kriteria perancangan yang digunakan untuk perancangan pengendali sebagai berikut

1. Waktu naik kurang dari 0.5000 detik.

2. Waktu puncak 1.5000 detik.

3. Waktu keadaan mantap kurang dari 2.5000 detik

4. Lewatan maksimum kurang dari $20.0000 \%$.

5. Nilai puncak kurang dari 1.2000

\section{Prosedur Analisa Peralihan Sistem AVR Tanpa dan Dengan Pengendali.}

Penelitian ini dimulai dengan pemodelan matematis sistem AVR tipe arus searah. Pemodelan matematis untuk sistem AVR tipe arus searah ini terdiri dari beberapa komponen diantaranya pemodelan amplifier, pemodelan eksiter, pemodelan generator dan pemodelan sensor. Pemodelan matematis AVR tipe arus searah ini menggunakan persamaan linear diferensial dan transformasi Laplace. Hasil pemodelan masing - masing komponen ini berupa fungsi alih orde satu. Fungsi alih dari masing-masing komponen ini kemudian digabungkan dan diperoleh fungsi alih lingkar terbuka dan fungsi alih lingkar tertutup. Adapun keluaran yang diamati adalah tanggapan tegangan sistem AVR tipe arus searah dan masukan adalah tanggapan tegangan referensi. Setelah diperoleh fungsi alih lingkar terbuka dan fungsi alih lingkar tertutup dari tanggapan tegangan sistem AVR tipe arus searah kemudian dilakukan substitusi nilai - nilai parameter setiap komponen. Adapun nilai - nilai parameter dari sistem Automatic Voltage Regulator (AVR) tipe arus searah diperlihatkan pada Tabel 1 sehingga diperoleh fungsi alih lingkar terbuka dan fungsi alih lingkar tertutup. Untuk fungsi alih lingkar terbuka secara lengkap diperlihatkan pada persamaan (30) dan untuk fungsi alih lingkar tertutup diperlihatkan pada persamaan (31).

Setelah diperolehnya fungsi alih lingkar terbuka dan fungsi alih lingkar tertutup dari sistem AVR tipe arus searah secara lengkap kemudian dilakukan dilakukan analisa tanggapan peralihan tegangan sistem AVR tipe arus searah tanpa pengendali. Untuk analisa peralihan dilakukan dengan menggunakan persamaan (31) dengan parameter yang diamati meliputi waktu naik, waktu puncak, waktu keadaan mantap, nilai puncak dan lewatan maksimum. Berdasarkan analisa peralihan tanpa pengendali ini kemudian ditentukan kriteria perancangan pengendali. Adapun kriteria perancangan pengendali diperlihatkan pada bagian $\mathrm{b}$ dari bagian 3 pada artikel ini.

Selanjutnya dilakukan perancangan pengendali tanggapan tegangan sistem AVR tipe arus searah dengan pengendali 2 derjat kebebasan. Pengendali yang dirancang terdiri dari pengendali Proporsional Diferensial (PD), Proporsional Integral (PI), Proporsional Integral Diferensial (PID), Proporsional Diferensial Dengan Filter Orde Satu Pada Bagian
Diferensial (PDF) dan Proporsional Intregral Diferensial Dengan Filter Orde Satu Pada Bagian Diferensial (PIDF). Perancangan pengendali ini dilakukan dengan menggunakan persamaan fungsi alih lingkar terbuka yang diperlihatkan pada persamaan (30). Hasil dari perancangan diperolehnya fungsi alih untuk masing masing pengendali., fungsi alih lingkar terbuka dengan pengendali dan fungsi alih lingkar tertutup dengan pengendali.

Setelah diperolehnya fungsi alih pengendali, fungsi alih lingkar terbuka dengan pengendali dan fungsi alih lingkar tertutup dengan pengendali maka dilakukan analisa performansi tanggapan peralihan tegangan sistem AVR tipe arus searah dengan pengendali. Analisa yang dilakukan sama dengan analisa performansi tanggapan tegangan sistem AVR tipe arus searah tanpa pengendali. Hasil analisa tanggapan peralihan tegangan sistem AVR tipe arus searah dengan pengendali ini kemudian dibandingkan dengan hasil analisa tanggapan peralihan tegangan sistem AVR tipe arus searah tanpa pengendali dengan menggunakan kriteria perancangan. Hasil dari perbandingan ini diperoleh informasi pengendali yang memenuhi kriteria perancangan untuk meningkatkan performansi tanggapan peralihan tegangan sistem AVR tipe arus searah.

\section{HASIL DAN PEMBAHASAN}

Bagian ini menjelaskan analisa peralihan tanggapan tegangan sistem AVR tipe arus searah tanpa dan dengan pengendali 2 derjat kebebasan. Untuk pengendali yang digunakan meliputi pengendali Proporsional Diferensial (PD), Proporsional Integral (PI), Proporsional Integral Diferensial (PID), Proporsional Diferensial Dengan Filter Orde Satu Pada Bagian Diferensial (PDF) dan Proporsional Intregral Diferensial Dengan Filter Orde Satu Pada Bagian Diferensial (PIDF). Adapun parameter yang hitung meliputi waktu naik, waktu puncak, waktu keadaan mantap, lewatan maksimum dan nilai puncak.

Untuk fungsi alih pengendali Proporsional Diferensial (PD) 2 derjat kebebasan diperlihatkan pada persamaan (13) berikut

$$
C(s)=1.24(r-y)+0.24 s(0.475 r-y)
$$

Hasil perhitungan nilai parameter peralihan tanggapan tegangan sistem AVR tanpa dan dengan pengendali Proporsional Diferensial (PD) 2 derjat kebebasan diperlihatkan pada Tabel 2 berikut

Tabel 2. Nilai Parameter Peralihan Sistem AVR Tipe Arus Searah

\begin{tabular}{lcc}
\hline \multicolumn{1}{c}{ Kriteria } & $\begin{array}{c}\text { Tanpa } \\
\text { Pengendali }\end{array}$ & $\begin{array}{c}\text { Dengan } \\
\text { Pengendali }\end{array}$ \\
\hline Waktu Naik & 0.1868 detik & 0.2808 detik \\
Waktu Puncak & 0.5162 detik & 1.3354 detik \\
Waktu Keadaan & 2.9466 detik & 0.7017 detik \\
Mantap & $52.3300 \%$ & $0 \%$ \\
Lewatan Maksimum & 1.4337 & 0.9512 \\
Nilai Puncak & & \\
\hline
\end{tabular}


Untuk tanggapan peralihan tegangan sistem AVR tipe arus searah tanpa dan dengan pengendali Proporsional Diferensial (PD) 2 derjat kebebasan diperlihatkan pada Gambar 4 berikut

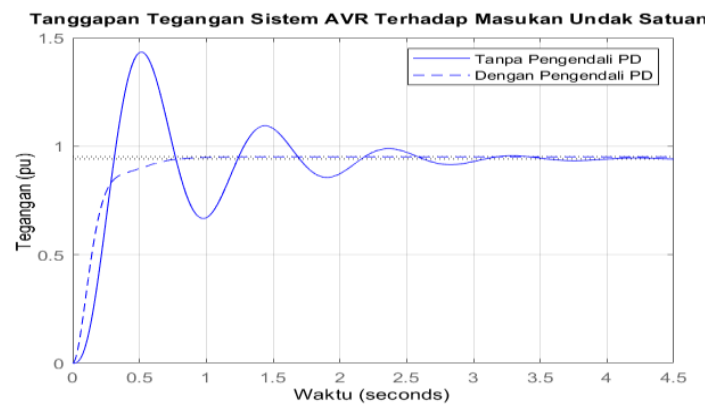

Gambar 4. Tanggapan Peralihan Sistem AVR Tipe Arus Terhadap Masukan Undak Satuan

Untuk fungsi alih pengendali Proporsional Integral (PI) 2 derjat kebebasan diperlihatkan pada persamaan (14) berikut

$$
C(s)=0.1010(0.2010 r-y)+\frac{0.1070}{s}(r-y)
$$

Hasil perhitungan nilai parameter peralihan tanggapan tegangan sistem AVR tanpa dan dengan pengendali Proporsional Integral (PI) 2 derjat kebebasan diperlihatkan pada Tabel 3 berikut

Tabel 3. Nilai Parameter Peralihan Sistem AVR Tipe Arus

\begin{tabular}{lcc}
\multicolumn{3}{c}{ Searah } \\
\multicolumn{1}{c}{ Kriteria } & Tanpa & Dengan \\
& Pengendali & Pengendali \\
\hline Waktu Naik & 0.1868 detik & 1.9343 detik \\
Waktu Puncak & 0.5162 detik & 4.1953 detik \\
Waktu Keadaan & 2.9466 detik & 4.5172 detik \\
Mantap & $52.3300 \%$ & $2.1572 \%$ \\
Lewatan Maksimum & 1.4337 & 1.0216 \\
Nilai Puncak & & \\
\hline
\end{tabular}

Untuk tanggapan peralihan tegangan sistem AVR tipe arus searah tanpa dan dengan pengendali Proporsional Integral (PI) 2 derjat kebebasan diperlihatkan pada Gambar 5 berikut

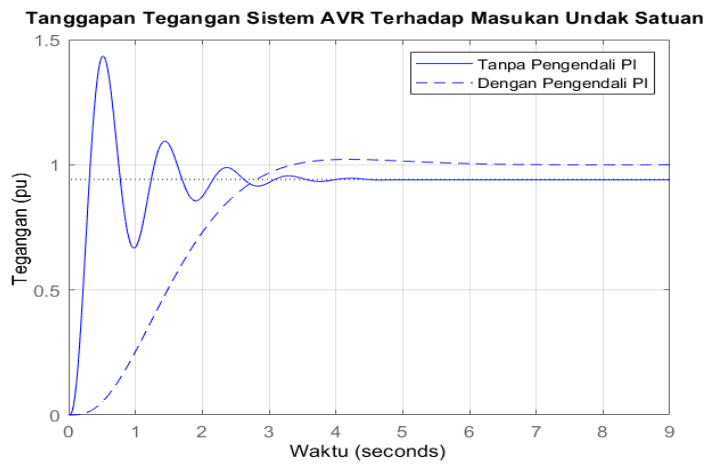

Gambar 5. Tanggapan Peralihan Sistem AVR Tipe Arus Terhadap Masukan Undak Satuan
Untuk fungsi alih pengendali Proporsional Integral Diferensial (PID) 2 derjat kebebasan diperlihatkan pada persamaan (15) berikut

$$
\mathrm{C}(\mathrm{s})=0.1190+\frac{0.1130}{\mathrm{~s}}(\mathrm{r}-\mathrm{y})-0.0263 \mathrm{sy}
$$

Hasil perhitungan nilai parameter peralihan tanggapan tegangan sistem AVR tanpa dan dengan pengendali Proporsional Integral Diferensial (PID) 2 derjat kebebasan diperlihatkan pada Tabel 4 berikut

Tabel 4. Nilai Parameter Peralihan Sistem AVR Tipe Arus Searah

\begin{tabular}{lcc}
\hline \multicolumn{1}{c}{ Kriteria } & $\begin{array}{c}\text { Tanpa } \\
\text { Pengendali }\end{array}$ & $\begin{array}{c}\text { Dengan } \\
\text { Pengendali }\end{array}$ \\
\hline Waktu Naik & 0.1868 detik & 2.1302 detik \\
Waktu Puncak & 0.5162 detik & 4.5615 detik \\
Waktu Keadaan & 2.9466 detik & 5.6979 detik \\
Mantap & $52.3300 \%$ & $3.2552 \%$ \\
Lewatan Maksimum & 1.4337 & 1.0326 \\
Nilai Puncak & & \\
\hline
\end{tabular}

Untuk tanggapan peralihan tegangan sistem AVR tipe arus searah tanpa dan dengan pengendali Proporsional Integral Diferensial (PID) 2 derjat kebebasan diperlihatkan pada Gambar 6 berikut

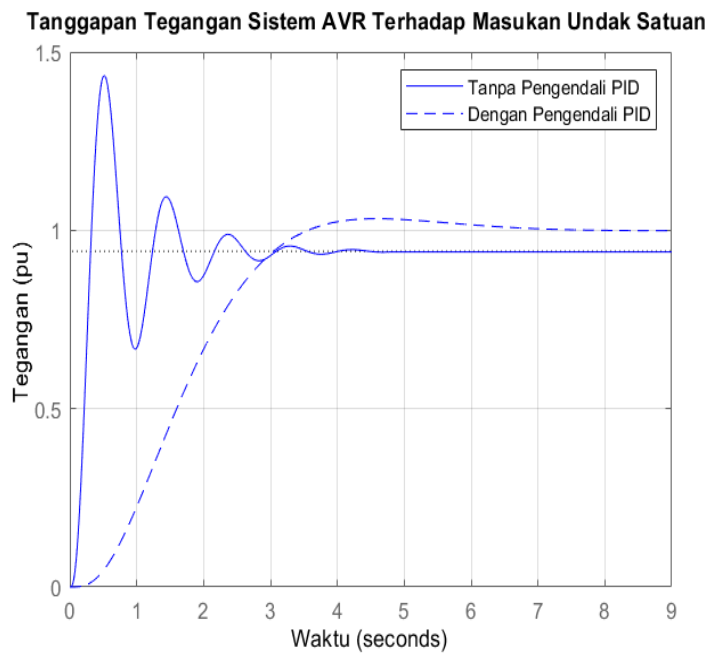

Gambar 6. Tanggapan Peralihan Sistem AVR Tipe Arus Terhadap Masukan Undak Satuan

Untuk fungsi alih pengendali Proporsional Diferensial Dengan Filter Orde Satu Pada Bagian Diferensial (PDF) 2 derjat kebebasan diperlihatkan pada persamaan (16) berikut

$$
\mathrm{C}(\mathrm{s})=1.2100(\mathrm{r}-\mathrm{y})+\frac{0.2420 \mathrm{~s}}{0.0008 \mathrm{~s}+1.0000}(0.0040 \mathrm{r}-\mathrm{y})(16)
$$

Hasil perhitungan nilai parameter peralihan tanggapan tegangan sistem AVR tanpa dan dengan pengendali Proporsional Diferensial Dengan Filter Orde Satu Pada Bagian Diferensial (PDF) 2 derjat kebebasan 2 derjat kebebasan diperlihatkan pada Tabel 5 berikut 
Tabel 5. Nilai Parameter Peralihan Sistem AVR Tipe Arus Searah

\begin{tabular}{lcc}
\hline \multicolumn{1}{c}{ Kriteria } & $\begin{array}{c}\text { Tanpa } \\
\text { Pengendali }\end{array}$ & $\begin{array}{c}\text { Dengan } \\
\text { Pengendali }\end{array}$ \\
\hline Waktu Naik & 0.1868 detik & 0.4177 detik \\
Waktu Puncak & 0.5162 detik & 1.4684 detik \\
Waktu Keadaan & 2.9466 detik & 0.8453 detik \\
Mantap & $52.3300 \%$ & $0 \%$ \\
Lewatan Maksimum & 1.4337 & 0.9502 \\
Nilai Puncak & &
\end{tabular}

Untuk tanggapan peralihan tegangan sistem AVR tipe arus searah tanpa dan dengan pengendali Proporsional Diferensial Dengan Filter Orde Satu Pada Bagian Diferensial (PDF) 2 derjat kebebasan diperlihatkan pada Gambar 7 berikut

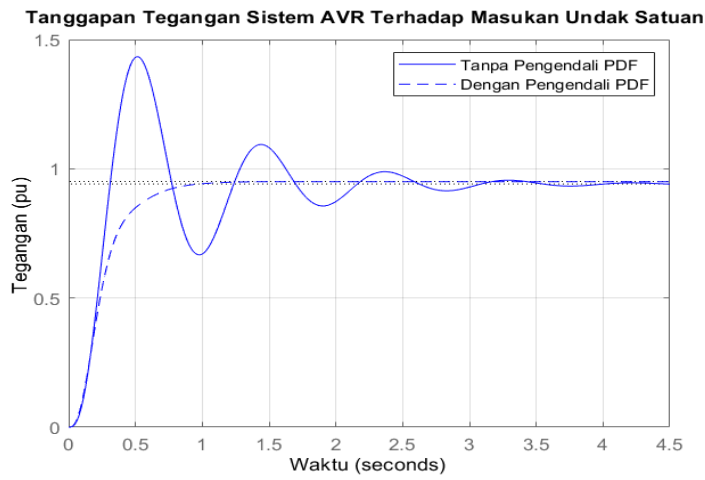

Gambar 7. Tanggapan Peralihan Sistem AVR Tipe Arus Terhadap Masukan Undak Satuan

Untuk fungsi alih pengendali Proporsional Intregral Diferensial Dengan Filter Orde Satu Pada Bagian Diferensial (PIDF) 2 derjat kebebasan diperlihatkan pada persamaan (17) berikut

$$
C(s)=0.1120(0.0807 r-y)+\frac{0.1050}{s}(r-y)-\frac{0.0160 s}{0.0786 s+1}(0.00002 r-y)
$$

Hasil perhitungan nilai parameter peralihan tanggapan tegangan sistem AVR tanpa dan dengan pengendali Proporsional Intregral Diferensial Dengan Filter Orde Satu Pada Bagian Diferensial (PIDF) 2 derjat kebebasan diperlihatkan pada Tabel 6 berikut

Tabel 6. Nilai Parameter Peralihan Sistem AVR Tipe Arus Searah

\begin{tabular}{|l|c|c|}
\hline \multicolumn{1}{|c|}{ Kriteria } & $\begin{array}{c}\text { Tanpa } \\
\text { Pengendali }\end{array}$ & $\begin{array}{c}\text { Dengan } \\
\text { Pengendali }\end{array}$ \\
\hline Waktu Naik & 0.1868 detik & 2.0863 detik \\
\hline Waktu Puncak & 0.5162 detik & 4.4662 detik \\
\hline $\begin{array}{l}\text { Waktu Keadaan } \\
\text { Mantap }\end{array}$ & 2.9466 detik & 5.3189 detik \\
\hline Lewatan Maksimum & $52.3300 \%$ & $2.8037 \%$ \\
\hline Nilai Puncak & 1.4337 & 1.0280 \\
\hline
\end{tabular}

Untuk tanggapan peralihan tegangan sistem AVR tipe arus searah tanpa dan dengan pengendali Proporsional Intregral Diferensial Dengan Filter Orde Satu Pada
Bagian Diferensial (PIDF) 2 derjat kebebasan diperlihatkan pada Gambar 8 berikut

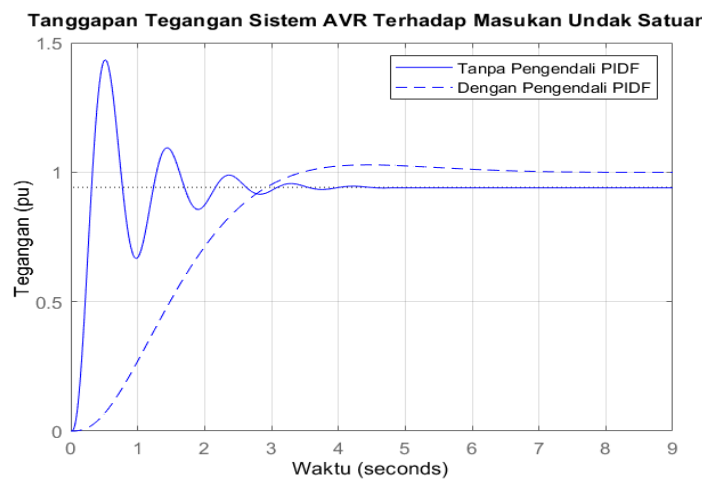

Gambar 8. Tanggapan Peralihan Sistem AVR Tipe Arus Terhadap Masukan Undak Satuan

Hasil simulasi memperlihatkan bahwa beberapa pengendali dari pengendali 2 derjat kebebasan memperlihatkan tanggapan peralihan tegangan sistem AVR tipe arus searah yang tidak memenuhi kriteria perancangan. Adapun jenis pengendali yang tidak memenuhi kriteria perancangan diantaranya pengendali Proporsional Integral (PI), Proporsional Integral Diferensial (PID) dan Proporsional Intregral Diferensial Dengan Filter Orde Satu Pada Bagian Diferensial (PIDF). Adapun parameter yang tidak memenuhi kriteria perancangan untuk ketiga pengendali adalah waktu naik, waktu puncak dan waktu keadaan mantap sedangkan untuk nilai puncak dan nilai lewatan maksimum sudah memenuhi kriteria perancangan.

Untuk pengendali yang memenuhi kriteria perancangan adalah Proporsional Diferensial (PD) dan Proporsional Diferensial Dengan Filter Orde Satu Pada Bagian Diferensial (PDF). Penambahan pengendali 2 derjat ini menyebabkan nilai parameter tanggapan peralihan menjadi lebih besar khususnya untuk waktu naik, waktu puncak dan waktu keadaan mantap sedangkan untuk nilai puncak dan nilai lewatan maksimum menjadi lebih kecil. Selain itu penambahan filter pada bagian diferensial untuk pengendali Proporsional Diferensial (PD) menyebabkan nilai parameter peralihan dari tanggapan peralihan tegangan sistem AVR tipe arus searah menjadi lebih lama tetapi masih memenuhi kriteria perancangan.

\section{PENUTUP}

\section{A. Kesimpulan}

Adapun kesimpulan dari penelitian ini sebagai berikut

1. Pengendali 2 derjat kebebasan yang memenuhi kriteria perancangan untuk pengendalian tanggapan peralihan sistem AVR tipe arus searah adalah pengendali Proporsional Diferensial (PD) dan 
Proporsional Diferensial Dengan Filter Orde Satu Pada Bagian Diferensial (PDF)

2. Adapun nilai parameter peralihan yang dipenuhi pengendali Proporsional Diferensial (PD) adalah waktu naik sebesar 0.2808 detik, waktu puncak sebesar 1.3354 detik, waktu keadaan mantap sebesar 0.7017 , lewatan maksimum sebesar $0 \%$ dan nilai puncak sebesar 0.9512 .

3. Untuk nilai parameter peralihan yang dipenuhi pengendali Proporsional Diferensial Dengan Filter Orde Satu Pada Bagian Diferensial (PDF) adalah waktu naik sebesar 0.4177 detik, waktu puncak sebesar 1.4684 detik, waktu keadaan mantap sebesar 0.8453 , lewatan maksimum sebesar $0 \%$ dan nilai puncak sebesar 0.9502 .

\section{B. Saran}

Beberapa saran yang dapat dilakukan dalam penelitian selanjutnya adalah

1. Selain analisa peralihan, hendaknya juga dilakukan analisa performansi dalam domain frekuensi untuk fungsi alih lingkar terbuka dan fungsi alih lingkar tertutup, analisa kestabilan, analisa kekokohan, analisa sensitivitas dan analisa waktu tunda.

2. Pada analisa kekokohan, pengaruh ketidakpastian hendaknya juga dimasukkan sehinga nantinya tanggapan tegangan sistem AVR tipe arus searah memiliki informasi performansi nominal, kestabilan nominal, performansi kokoh dan kestabilan kokoh yang lebih yang baik.

\section{REFERENSI}

[1] Graham, R, "Power System Oscillations", Kluwer Academic Publisher, Massachusetts, 1999.

[2] Sahib, M "A Novel Optimal PID Plus Second Oder Drivative Cntroller for AVR system", Engineering Science and Technology, $194-206,2015$.

[3] Bhatt, V. K., \& Bhongade, S, "Design of PID Controller In Automatic Voltage Regulator (AVR) Using PSO Technique", International Journal of Engineering Research and Applications, 1480 1485, 2013.

[4] Saadat, H. "Power System Analysis", McGraw Hill, New York, 1999.

[5] J. Faiz, G.H. Shahgholian \& Arezoomand, M, "Analysis and Simulation of The AVR System and Parameters Variation Effects", Powereng, 450 453, 2017.

[6] Araki, Mituhiko \& Taguchi, Hidefumi, "Two Degree of Freedom PID Controllers", International Journal of Control, Automation and Systems, 401 411, 2003.

[7] Franklin, G., Powell , J., \& Naeini , A. E. (1986). Feedback Control of Dynamics Systems . New York : Addison - Wesley Publishing Company.

[8] Ogata, K. (2010). Modern Control Engineering . 